\section{National Black HIV/AIDS Awareness Day - February 7, 2016}

February 7 is National Black HIV/AIDS Awareness Day, which is intended to raise awareness of human immunodeficiency virus (HIV) infection, which causes acquired immunodeficiency syndrome (AIDS). The observance also encourages action, such as HIV testing, to reduce the disproportionate impact of HIV/AIDS on nonHispanic blacks/African Americans (blacks) in the United States. From 2010 to 2014, the annual HIV diagnosis rate decreased for blacks (1). However, blacks continued to account for nearly half of all HIV diagnoses each year, with most diagnoses occurring among gay and bisexual men (2).

In 2014, blacks accounted for $44 \%$ of new HIV diagnoses, with men accounting for $73 \%$ of these diagnoses (1). The annual HIV diagnosis rate for black women $(30.0$ per 100,000) was 18 times the rate for white women (1.7) and five times the rate for Hispanic/Latino women (6.5). Among blacks living with HIV in 2011, $85 \%$ received an HIV diagnosis, $40 \%$ were engaged in HIV care, $36 \%$ were prescribed antiretroviral therapy, and $28 \%$ were virally suppressed (3).

Additional information is available online regarding National Black HIV/AIDS Awareness Day (http://www. cdc.gov/features/blackhivaidsawareness) as well as blacks and HIV/AIDS (http://www.cdc.gov/hiv/group/racialethnic/africanamericans/index.html).

\section{References}

1. Frieden TR, Foti KE, Mermin J. Applying public health principles to the HIV epidemic-how are we doing? N Engl J Med 2015;373:2281-7. http://dx.doi.org/10.1056/NEJMms1513641.

2. CDC. HIV surveillance report, 2014; Vol. 26. Atlanta, GA: US Department of Health and Human Services, CDC; 2015. http:// www.cdc.gov/hiv/library/reports/surveillance/.

3. Bradley H, Hall HI, Wolitski RJ, et al. Vital signs: HIV diagnosis, care, and treatment among persons living with HIV_-United States, 2011. MMWR Morb Mortal Wkly Rep 2014;63:1113-7.

\section{Disparities in Consistent Retention in HIV Care - 11 States and the District of Columbia, 2011-2013}

\author{
Sharoda Dasgupta, $\mathrm{PhD}^{1,2}$; Alexandra M. Oster, $\mathrm{MD}^{1}$; \\ Jianmin Li, $\mathrm{DPE}^{1}$; H. Irene Hall, $\mathrm{PhD}^{1}$
}

In 2013, 45\% of new human immunodeficiency virus (HIV) infection diagnoses occurred in non-Hispanic blacks/ African Americans (blacks) (1), who represent $12 \%$ of the U.S. population.* Antiretroviral therapy (ART) improves clinical outcomes and reduces transmission of HIV, which causes acquired immunodeficiency syndrome (AIDS) (2). Racial/ ethnic disparities in HIV care limit access to ART, perpetuating disparities in survival and reduced HIV transmission. National HIV Surveillance System (NHSS) data are used to monitor progress toward reaching the National HIV/AIDS Strategy

${ }^{*}$ U.S. Census Bureau. Population estimates. http://www.census.gov/popest/data/.

\section{INSIDE}

83 HIV Testing and Service Delivery Among Black Females - 61 Health Department Jurisdictions, United States, 2012-2014

86 Advisory Committee on Immunization Practices Recommended Immunization Schedules for Persons Aged 0 Through 18 Years — United States, 2016

88 Advisory Committee on Immunization Practices Recommended Immunization Schedule for Adults Aged 19 Years or Older — United States, 2016

91 Vital Signs: Alcohol-Exposed Pregnancies — United States, 2011-2013

98 Announcement

99 QuickStats

Continuing Education examination available at http://www.cdc.gov/mmwr/cme/conted_info.html\#weekly.

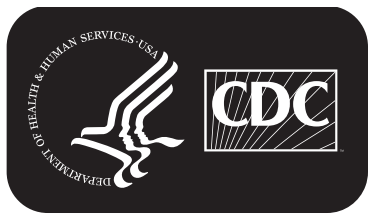

U.S. Department of Health and Human Services Centers for Disease Control and Prevention 